\title{
A Tanári IKT-kompetencia Közös Európai Referenciakerete - U-Teacher
}

\section{Bevezetés}

Az információs és kommunikációs technológiai eszközök gyors fejlődése következtében mindennapi életünk részeivé váltak. Ezek a folyamatok kihatással voltak az oktatásra is. Az IKT-eszközök ma már segítséget és támogatást nyújtó alapeszközökként vannak jelen az oktatásban. Szinte minden diák hozzáfér vagy rendelkezik személyi számítógéppel, és egyre többen használnak okostelefont vagy táblagépet is. A korábbi pedagógiai módszerek jelentős része az új tanításitanulási környezetben már nem állja meg a helyét. Az új kihívások szükségessé teszik új kompetenciák meglétét a pedagógusok számára annak érdekében, hogy megfelelően alkalmazkodhassanak a korszerü oktatás követelményeihez. Mindez a tanárképzés és a továbbképzés számára új feladatokat fogalmaz meg. Olyan képességstruktúra kialakítását teszi szükségessé, amelyben az informatikai kompetencia összetevői együtt vannak jelen a pedagógus képességekkel. Az informatikai eszközöket hatékonyan alkalmazni képes tanárok víziója jelenik meg előttünk. Az előbb felvázolt kihívásra adott egyik lehetséges válasz a Tanári IKTkompetencia Közös Európai Referenciakeret. Elemzésünkben rövid áttekintést adunk a modell kidolgozásának menetéről, majd ismertetjük annak irányelveit, statikus és dinamikus felfogásának dimenzióit, bemutatjuk magát a referenciakeretet különös tekintettel a szakmai kompetencia profilokra, majd röviden szót ejtünk hatásáról a kidolgozást követő időszakra.

\section{A U-Teacher Project célja}

2005-ben jelent meg a U-Teacher -a Tanári IKT-kompetencia Közös Európai Referenciakerete, amelynek célja a pedagógusok IKT-kompetencia szintjének meghatározásához és fejlesztéséhez egy elméleti modell megalkotása volt. A 
koncepció alapját a Közös Európai Nyelvi Referenciakeret (KER - Common European Framework of Reference for Languages, CEFR) a nyelvtudás szintjének Európa-szerte egységes meghatározására kidolgozott útmutató jelentette. Ez a jelenleg is érvényben lévő referenciakeret közös kiindulási alapként szolgál nyelvi tantervek, tantervi útmutatók, vizsgák és tankönyvek kidolgozásához (Racskó, 2016).

A modell megalkotását megelőzte az U-Tanár Kutatási Program (U-Teacher Project), amely 2003 és 2005 között zajlott. A kutatást az az igény hívta életre, hogy szükségessé vált bizonyos oktatáspolitikai döntések meghozatala a pedagógusok informatikai kompetenciájának fejlesztése, és ennek eredményeként a digitális pedagógia módszereinek elterjesztése érdekében. Maga a kutatás áttekintette a pedagógusok számára az oktatás szempontjából releváns IKTismereteit, készségeit, majd megfogalmazta a fejlesztésükhöz szükséges intézkedéseket is a tanárképzéstől az iskolák felszereltségén és fenntartható fejlesztésén át a folyamatos segítségadásig, a továbbképzésekig. A kutatás eredményeként ajánlások kerültek megfogalmazásra (Midoro, 2005), amelyek a pedagógusképzés szerepét hangsúlyozták a digitális pedagógia egész pedagógiai rendszerbe történő beillesztéséhez. Az ajánlások nem annyira a hallgatók technikai felkészítését helyezték előtérbe, hanem inkább a digitális pedagógia módszereinek megismertetését. A rendszert két tanulmányban mutatta be részletesen Kárpáti Andrea és Hunya Márta (Kárpáti és Hunya, 2009a; Kárpáti és Hunya, 2009b).

\section{A U-Teacher Project fázisai}

Maga a kutatási projekt három egymást követő fázisból épült fel. Először létrejött egy nemzetközi kutatócsoport, amelyet Vittorio Midoro vezetett, és egy valódi gyakorlatközösségként müködött. A kutatócsoport célja az volt, hogy alapos áttekintést nyújtson arról, hogy a különböző európai országokban milyen szinteken, milyen kompetencia profilokkal folyik a leendő és gyakorló pedagógusok IKT-képzése. További célként fogalmazódott meg a pedagógusképzésben és továbbképzésben az IKT-készségek fejlesztési szintjeinek meghatározása.

A második fázisban, sor került az egyes európai országokon belül a pedagógusok IKT-szakmai profiljának meghatározása annak alapján, hogy az adott országokban a tanárképzésbe és továbbképzésbe hogyan épült be az IKT-képzés. A tizenkilenc kutató munkájának eredményeit a European Teachers Towards the Knowledge Society címü kötetben publikálták. 
A harmadik fázisban, amelybe Magyarország részéről bekapcsolódott Kárpáti Andrea, kidolgozásra került a pedagógusok szakmai fejlődését, azon belül pedig az IKT-kompetenciák fejlődését elősegítő Közös Európai Referenciakeret, amelyet a Common European Framework for Teachers' Professional Profile in ICT for Education címü könyvben publikáltak.

\section{A kutatás módszere}

Az előbbiekben már említettük, hogy minden résztvevő ország delegált egy kutatót a nemzetközi csoportba. A delegáltak feladata az volt, hogy részletes jelentést írjanak a saját országukban, a tanárképzésben és továbbképzésben folyó IKT-képzésekről. Fontos volt, hogy egy előre meghatározott szempontrendszer alapján történt mindez, következésképpen ki kellett dolgozni magát a szempontrendszert. A kutatók egy részletes mintát kaptak, ahol fogalommagyarázattal és konkrét példákkal segítették a munkájukat. A szempontok az IKT-képzés két nagy területére fókuszáltak: a tanárképzésben és a továbbképzésekben folyó képzésekre. Ezeken belül a következő területeket vizsgálták:

1. A képzések céljai, szakmai területek, amelyekre vonatkoztak a képzések, és szakmai szervezeti egységek (beleértve személyeket is) amelyek fejlesztésére vonatkoztak a képzések.

2. A tanárképzésben és továbbképzésben megvalósuló IKT-képzések tantervi felépítése (adott tanulói csoporton belül a tanulók készségeinek fejlesztése, a pedagógusok együttmüködésének fejlesztése, az iskola, mint szervezet fejlesztése, a pedagógusok szakmai fejlődésének elösegítése hogyan valósul meg).

3. A pedagógusok IKT-kompetencia profilja.

A kutatók a projekt ideje alatt egy közös (MOODLE) platformon dolgoztak, következetesen adminisztrálva a tevékenységüket. A távmunka mellett projekt találkozókra is sor került. Az első egyhetes találkozón a résztvevők kidolgozták a leendő referenciakeret céljait és tulajdonságait, bemutatták egymásnak a különböző országokban létező IKT-kompetencia profilokat, megvitatták azok azonos és eltérő vonásait, a kész jelentéseket egységesítették publikációs céllal, majd megvitatták a leendő közös referenciakeret országukban történő bevezetésének stratégiáit, bizonyos, a nemzeti karakterhez illeszkedő adaptív változtatások lehetőségét. A projekt második nagy fázisát lezáró szakasz eredménye lett a korábban már említett European Teachers Towards the Knowledge Society címü kötet. 
A következö projekttalálkozóra Palermóban került sor. Két célja volt az eseménynek:

1. az eddig elért eredmények disszeminációja,

2. a Közös Európai Referenciakeret részletes kidolgozása.

A munka eredményeként született meg a Common European Framework for Teachers' Professional Profile in ICT for Education címü kötet (Midoro és mtsai, 2005).

\section{A 2005-ös Közös Európai Referenciakeret főbb irányelvei}

Kiindulásként az ajánlások tisztázni kívánták az IKT iskolai szerepét és ennek tükrében vizsgálták felül a pedagógus, a pedagógus közösség, az iskolai vezetés tevékenységét és az iskola, mint szervezet müködését. A koncepció szerint a pedagógus, miután felmérte saját oktatási módszereit és feladatait, fogalmazza meg, milyen informatikai megoldások segíthetnék hatékonyabbá tenni munkáját. Ahelyett tehát, hogy kívülről jövő, sokszor érthetetlen elvárásoknak felelne meg, és személyiségétől idegen szerepekkel barátkozna, induljon ki abból, amivel elégedetlen, és erre keressen megoldást, majd ehhez tartozó képzést. Az iskola vezetöinek hasonlóan át kell tekintenie, mennyire kielégítő a szervezés, eljutnak-e a fontos közlemények minden érdekelthez, méltó képet mutat-e a külvilág felé az iskola. Ha van javítani való, érdemes IKT megoldásokat keresni. Ha minden tökéletesen müködik, akkor arra lehet figyelmet fordítani, hogy a befektetett munka nem csökkenthetö-e egy hatékonyabb számítógépes módszerrel, nincs-e olyan alkalmazás, amely gazdagítaná az iskola életét. (Midoro, 2005a, idézi Kárpáti, 2007). Alapvetően a reflektív gyakorlat dimenziói rajzolódnak ki elöttünk, amelyek az egyéntől, vagyis a pedagógustól elvezet az iskolavezetés és az iskola, mint szervezet szintjére és figyelembe veszi annak kölcsönhatásait az azt körülvevő társadalmi és technikai környezettel. A referenciakeret központjában tehát az innovatív pedagógus áll, aki egy komplex személyiség, és akinek számos területen kell helytállnia.

A 2005-ös referenciakeret koncepciójának értelmezéséhez nélkülözhetetlen bizonyos korábbi, az UNESCO által meghatározott kompetenciák ismertetése. Már a 2002-es UNESCO (Anderson van Weert és Duchâteau, 2002) ajánlásokban is jól elkülöníthetők bizonyos személyiségtulajdonságok és kompetenciák. Ezek fejlesztése három fő cél megvalósítására irányult:

- a pedagógus személyiségének fejlesztése,

- a pedagógiai és IKT-tudás megszerzése, 
- mindezek integrálása.

E célok megvalósítását, a képzés módszerének kidolgozását a képző intézményekre bízták. A legfontosabb személyiségtulajdonságokként az IKTeszközök használatával kapcsolatosan a következőket jelölték meg:

- kreativitás,

- rugalmasság,

- $\quad$ szervezési és adminisztrációs/dokumentálási készségek,

- $\quad$ együttmüködési készség.

Az UNESCO 2002-es rendszerében négy kompetenciaterületet különböztethető meg:

Pedagógiai kompetenciák: a tanár oktatási gyakorlata, amelyben

- felhasználja az IKT-módszereket és -tartalmakat,

- felismeri, hogy tantárgya keretében mely témaköröknél, milyen módon használhat IKT-eszközöket a tantervi követelményekhez kapcsolva,

- képes megtervezni, megszervezni és lefolytatni távoktatásos és jelen idejü képzési elemeket egyaránt tartalmazó, nyitott és rugalmas oktatási keretrendszerben megvalósított pedagógiai programokat,

- $\quad$ képes ezeket a folyamatokat értékelni és megújítani.

Együttmüködés, hálózatépités: az IKT-technológiák használata nem ér véget az osztályterem ajtajánál, ellenkezőleg: lehetőséget nyújt a tanárnak arra, hogy

- $\quad$ szakmai közösségekhez csatlakozzon, maga is létrehozzon ilyeneket,

- értékelje és felhasználja a tanulási hálózatok előnyeit,

- maga is képes legyen olyan hálózatokat létrehozni, amelyek többletértéket visznek az oktatásba,

- együttmüködésre képes országon belül és nemzetközi keretek között,

- képes tanulóként és tanárként egyaránt dolgozni a nyitott és rugalmas elearning- rendszerekben,

- képes különféle képességekkel, adottságokkal és társadalmi háttérrel rendelkező tanulóknak megfelelő tanulási környezetet kialakítani, beleértve a fogyatékkal élőket is. 
Az információs társadalom problémái és az informatikai eszközök használatában rejlő egészségügyi kockázatok felismerése és kezelése. A tanár

- megérti és képes használni az informatikai eszközökkel kapcsolatos jogi és erkölcsi szabályokat,

- tiszteletben tartja a szellemi tulajdont,

- értékeli és másokkal is megvitatja az új technológiák hatását a társadalomra,

- megtervezi a környezetet, és bevezeti azokat a szabályokat, amelyek szükségesek az egészséges IKT-használathoz (megfelelö munkakörülmények: ülés, megvilágítás, hang, környezettudatos energiafelhasználás stb.).

Egész életen át tartó tanulás: a folyamatosan korszerüsödő technika releváns elemeinek megismerése, integrálása már birtokolt oktatási informatikai ismeretés képességrendszerbe. A tanár

- olyan IKT-eszközöket alkalmaz, amelyek növelik a személyes és a szakmai hatékonyságot,

- rendszeresen fejleszti tudását az új fejlesztések oktatási felhasználása végett. (Anderson, van Weert és Duchâteau, 2002,71-75. idézi Kárpáti és Hunya, 2009b).

A továbbiakban a 2005-ös referenciakeret ismertetésére vállalkozunk, amely jóval túlhaladta a 2002-es rendszert. Valójában egy elméleti modell megalkotására került sor, amelybe belehelyezték a korábbi személyiségtulajdonságokat, kompetenciákat, ugyanakkor kitágították annak dimenzióit. A modellt statikusan és dinamikusan is ábrázolták. Felmerül a kérdés hogy, miért volt szükség e kétféle leírásra. A statikus ábrázolás célja az volt, hogy a pedagógus által végzett szakmai tevékenységet egyrészt társadalmi kapcsolatain keresztül (személyek, szervezetek, akikkel munkája során érintkezik), másrészt szakmája specifikus kontextusaiban (ahol a tevékenysége zajlik) mutassa be. A Szereplök és a Területek közös pontja az a szándék, amellyel a tanár az IKT-t, mint az innováció motorját alkalmazza az osztályban, s az a képesség, hogy az oktatás átalakításának aktív szereplője legyen (Kárpáti és Hunya, 2009b). 


\begin{tabular}{|c|c|c|c|c|}
\hline $\begin{array}{l}\text { Szereplők } \\
\text { Területek }\end{array}$ & $\begin{array}{l}\text { A tanár maga } \\
\text { A tanári } \\
\text { személyiség } \\
\text { folyamatos } \\
\text { építése }\end{array}$ & $\begin{array}{l}\text { Tanulók } \\
\text { A tanulók } \\
\text { tanulásának és } \\
\text { fejlődésének } \\
\text { elősegítése }\end{array}$ & $\begin{array}{l}\text { Kollégák } \\
\text { Együttműködés } \\
\text { az iskolában és } \\
\text { egyéb tanári } \\
\text { közösségekkel }\end{array}$ & \begin{tabular}{|l} 
Környezet \\
Interakciók az \\
iskola külső \\
környezetével
\end{tabular} \\
\hline Pedagógia & $\begin{array}{l}\text { Az IKT tanulásra, } \\
\text { iskolára és } \\
\text { társadalomra } \\
\text { gyakorolt } \\
\text { hatásának } \\
\text { tudatosulása }\end{array}$ & $\begin{array}{l}\text { Olyan tanulási } \\
\text { környezet } \\
\text { kialakítása, } \\
\text { amely } \\
\text { összhangban } \\
\text { van személyes } \\
\text { víziójával és a } \\
\text { tudástársadalom } \\
\text { kihívásaival }\end{array}$ & $\begin{array}{l}\text { A vízió, a } \\
\text { tapasztalatok és a } \\
\text { módszerek } \\
\text { megosztása } \\
\text { Együttmüködés } \\
\text { interdiszcipliná- } \\
\text { ris oktatási } \\
\text { tevékenységek- } \\
\text { ben }\end{array}$ & $\begin{array}{l}\text { A helyi és a } \\
\text { globális } \\
\text { környezet } \\
\text { felhasználása } \\
\text { a tanulás } \\
\text { forrásaként és } \\
\text { színtereként }\end{array}$ \\
\hline $\begin{array}{l}\text { Tanterv, } \\
\text { tanmenet, } \\
\text { tananyag }\end{array}$ & $\begin{array}{l}\text { Az IKT szerepe a } \\
\text { tantárgy } \\
\text { tanításában a } \\
\text { tudástartalom } \\
\text { gyors } \\
\text { növekedésére } \\
\text { való tekintettel, a } \\
\text { tantárgy } \\
\text { kulcsterületeire }\end{array}$ & $\begin{array}{l}\text { Olyan tanulási } \\
\text { környezet } \\
\text { tervezése és } \\
\text { kialakítása, } \\
\text { amely számol } \\
\text { az IKT } \\
\text { lehetőségeivel } \\
\text { és korlátaival az } \\
\text { adott } \\
\text { szakterületen }\end{array}$ & $\begin{array}{l}\text { Az IKT-használat } \\
\text { tapasztalatainak } \\
\text { és módszereinek } \\
\text { megosztása az } \\
\text { iskolában és } \\
\text { egyéb tanári } \\
\text { közösségekkel }\end{array}$ & $\begin{array}{l}\text { A helyi és a } \\
\text { globális } \\
\text { források } \\
\text { kihasználása } \\
\text { az adott } \\
\text { tantárgy } \\
\text { tanulásának } \\
\text { elömozdításá- } \\
\text { ra }\end{array}$ \\
\hline Szervezet & $\begin{array}{l}\text { Személyes vízió } \\
\text { kialakítása a } \\
\text { tudástársadalom } \\
\text { követelményeinek } \\
\text { megfelelő } \\
\text { iskolaszervezetről }\end{array}$ & $\begin{array}{l}\text { A korlátokon } \\
\text { belül olyan } \\
\text { iskolai / } \\
\text { osztályszerve- } \\
\text { zet kialakítása, } \\
\text { amely megfelel } \\
\text { a tudástársada- } \\
\text { lom } \\
\text { kihívásainak }\end{array}$ & $\begin{array}{l}\text { Tapasztalatok, } \\
\text { módszerek és } \\
\text { szervezeti } \\
\text { elképzelések } \\
\text { megosztása, } \\
\text { együttmúködés az } \\
\text { osztály- és } \\
\text { iskolaszervezet } \\
\text { átalakításában }\end{array}$ & $\begin{array}{l}\text { Közremükö- } \\
\text { dés a helyi és } \\
\text { a globális } \\
\text { környezethez } \\
\text { kapcsolódó } \\
\text { iskolaszerve- } \\
\text { zet } \\
\text { kialakításában }\end{array}$ \\
\hline
\end{tabular}




\begin{tabular}{|c|c|c|c|c|}
\hline $\begin{array}{l}\text { Szereplők } \\
\text { Területek }\end{array}$ & $\begin{array}{l}\text { A tanár maga } \\
\text { A tanári } \\
\text { személyiség } \\
\text { folyamatos } \\
\text { építése }\end{array}$ & $\begin{array}{l}\text { Tanulók } \\
\text { A tanulók } \\
\text { tanulásának és } \\
\text { fejlődésének } \\
\text { elősegítése }\end{array}$ & $\begin{array}{l}\text { Kollégák } \\
\text { Együttműködés } \\
\text { az iskolában és } \\
\text { egyéb tanári } \\
\text { közösségekkel }\end{array}$ & $\begin{array}{l}\text { Környezet } \\
\text { Interakciók az } \\
\text { iskola külső } \\
\text { környezetével }\end{array}$ \\
\hline Technológia & $\begin{array}{l}\text { A technikai tudás } \\
\text { folyamatos } \\
\text { fejlesztése }\end{array}$ & $\begin{array}{l}\text { A megfelelő } \\
\text { IKT-eszközök } \\
\text { kiválasztása a } \\
\text { tanulás } \\
\text { segítésére }\end{array}$ & $\begin{array}{l}\text { Az IKT-eszközök } \\
\text { használata } \\
\text { szakmai } \\
\text { kommunikációra }\end{array}$ & $\begin{array}{l}\text { Hozzáadott } \\
\text { értéket } \\
\text { képviselő } \\
\text { helyi és } \\
\text { globális } \\
\text { tanulási } \\
\text { hálózatok } \\
\text { kialakítása }\end{array}$ \\
\hline $\begin{array}{l}\text { Szakmai } \\
\text { fejlődés }\end{array}$ & $\begin{array}{l}\text { A folyamatos } \\
\text { szakmai fejlődés } \\
\text { szükségességé- } \\
\text { nek és } \\
\text { lehetőségeinek } \\
\text { felismerése }\end{array}$ & $\begin{array}{l}\text { Szakmai } \\
\text { fejlődés } \\
\text { tervezése és } \\
\text { megvalósítása a } \\
\text { tanulók } \\
\text { fejlődése és } \\
\text { jóléte } \\
\text { érdekében }\end{array}$ & $\begin{array}{l}\text { Az IKT } \\
\text { lehetőségeinek } \\
\text { megismerése a } \\
\text { szakmai } \\
\text { kommunikáció- } \\
\text { ban }\end{array}$ & $\begin{array}{l}\text { A helyi és a } \\
\text { globális } \\
\text { környezet } \\
\text { által kínált } \\
\text { szakmai } \\
\text { fejlődési } \\
\text { lehetőségek } \\
\text { megismerése } \\
\text { és kiaknázása }\end{array}$ \\
\hline Etika & $\begin{array}{l}\text { A gyerekek } \\
\text { tanításának és } \\
\text { jólétének } \\
\text { elsődleges céllá } \\
\text { emelése, az IKT } \\
\text { fontos szerepének } \\
\text { elfogadása a } \\
\text { tudástársadalom } \\
\text { kialakításában }\end{array}$ & $\begin{array}{l}\text { Annak } \\
\text { elfogadása, } \\
\text { hogy a rábízott } \\
\text { tanulók } \\
\text { oktatása és } \\
\text { jóléte a tanár } \\
\text { elsődleges } \\
\text { felelőssége }\end{array}$ & $\begin{array}{l}\text { Pozitív és aktív } \\
\text { szerep az IKT- } \\
\text { eszközök és } \\
\text { források } \\
\text { szakszerü } \\
\text { használatában }\end{array}$ & $\begin{array}{l}\text { A felelősség } \\
\text { felismerése a } \\
\text { szociális és } \\
\text { fizikai } \\
\text { környezettel } \\
\text { harmóniában } \\
\text { élő } \\
\text { állampolgár- } \\
\text { ok } \\
\text { nevelésében }\end{array}$ \\
\hline
\end{tabular}




\begin{tabular}{|c|c|c|c|c|}
\hline $\begin{array}{l}\text { Szereplők } \\
\text { Területek }\end{array}$ & $\begin{array}{l}\text { A tanár maga } \\
\text { A tanári } \\
\text { személyiség } \\
\text { folyamatos } \\
\text { építése }\end{array}$ & $\begin{array}{l}\text { Tanulók } \\
\text { A tanulók } \\
\text { tanulásának és } \\
\text { fejlődésének } \\
\text { elösegítése }\end{array}$ & $\begin{array}{l}\text { Kollégák } \\
\text { Együttmüködés } \\
\text { az iskolában és } \\
\text { egyéb tanári } \\
\text { közösségekkel }\end{array}$ & $\begin{array}{l}\text { Környezet } \\
\text { Interakciók az } \\
\text { iskola külső } \\
\text { környezetével }\end{array}$ \\
\hline $\begin{array}{l}\text { Szakma- } \\
\text { politika }\end{array}$ & $\begin{array}{l}\text { A kormányzat } \\
\text { IKT-politikája és } \\
\text { stratégiája iskolai } \\
\text { megvalósulásának } \\
\text { kritikus } \\
\text { szemlélete, saját } \\
\text { vízió kialakítása }\end{array}$ & $\begin{array}{l}\text { A tantárgy } \\
\text { tartalmi } \\
\text { korlátainak } \\
\text { figyelembe } \\
\text { vételével a } \\
\text { szakmapoliti-ka } \\
\text { célkitü-zéseinek } \\
\text { megvalósítása. }\end{array}$ & $\begin{array}{l}\text { A kormányzat } \\
\text { IKT-politikája és } \\
\text { stratégiája iskolai } \\
\text { megvalósulásának } \\
\text { kritikus } \\
\text { szemlélete, } \\
\text { implementálás és } \\
\text { értékelés }\end{array}$ & $\begin{array}{l}\text { Az egyén } \\
\text { adott korlátai } \\
\text { között } \\
\text { hozzájárulás a } \\
\text { szakpolitika } \\
\text { IKT-célkitü- } \\
\text { zéseinek } \\
\text { kialakításá- } \\
\text { hoz, az adott } \\
\text { környezetre } \\
\text { vonatkozóan }\end{array}$ \\
\hline Innováció & $\begin{array}{l}\text { Kritikus, aktív és } \\
\text { szerepvállalás az } \\
\text { IKT-vezérelt } \\
\text { innovációban és } \\
\text { az átalakulásban }\end{array}$ & $\begin{array}{l}\text { Az IKT- } \\
\text { vezérelt } \\
\text { változások } \\
\text { alakítása és } \\
\text { újraalakítása a } \\
\text { tanulás és a } \\
\text { tanítás területén }\end{array}$ & $\begin{array}{l}\text { Együttműködés } \\
\text { az innovatív IKT- } \\
\text { használat } \\
\text { kialakításában és } \\
\text { alkalmazásában }\end{array}$ & $\begin{array}{l}\text { A tájékozott- } \\
\text { ságon alapuló } \\
\text { változás } \\
\text { kultúrájának } \\
\text { kialakításá- } \\
\text { hoz való } \\
\text { hozzájárulás } \\
\text { az iskolán } \\
\text { kívül, } \\
\text { szélesebb } \\
\text { körben }\end{array}$ \\
\hline
\end{tabular}

\section{1. táblázat: A Közös Európai Pedagógus IKT-kompetencia Referenciakeret szerkezete (Kárpáti és Hunya, 2009b)}

A statikus modell egyik dimenziója olyan területek összessége, amelyeken a pedagógus az IKT-val, mint a fejlődés eszközével találkozik:

- pedagógia,

- tanterv, tanmenet, tananyag;

- $\quad$ szervezet,

- technológia, 
- $\quad$ szakmai fejlődés,

- etika,

- $\quad$ szakmapolitika.

A statikus modell másik dimenziója, hogy a tevékenység során éppen mely szereplők érintettek az adott folyamatban:

- a tanár maga - a tanárszemélyiség folyamatos építése;

- tanulók - a tanulók tanulásának és fejlődésének elősegítése;

- $\quad$ kollégák - együttmúködés az iskolában és egyéb tanári közösségekkel;

- $\quad$ környezet - interakciók az iskola külső környezetével.(Racskó, 2016. 54)

A keretrendszert nem csak statikusan, hanem dinamikusan is ábrázolni kívánták a kidolgozói:

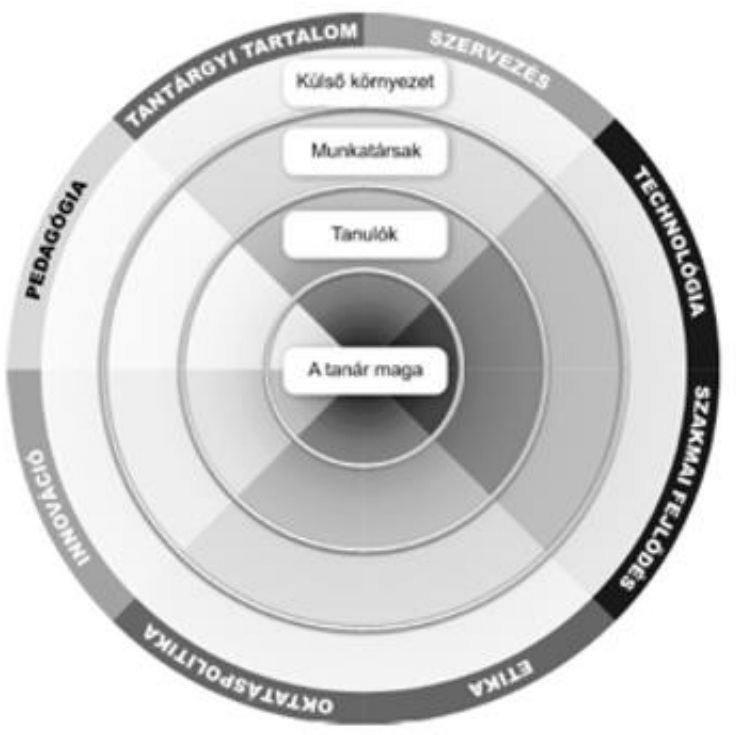

10. ábra: Tanári értékek a tudástársadalomban (Kárpáti és Hunya, 2009b)

A dinamikus ábrázolás egy komplex rendszerben értelmezte a pedagógust és annak tevékenységrendszerét, aki igyekszik adaptívan alkalmazkodni a társadalmi 
változások és a technikai fejlődés által létrehozott új elvárásokhoz. A modell az egyénből indul ki. A koncentrikus körök cikkei az adott szakmaterületen mutatják be a pedagógustól elvárt emberi, szakmai tulajdonságok, értékek körét, amelyek önmagával, a tanulókkal, a kollégáival és a külső környezettel való kapcsolatban kell, hogy megjelenjenek. A modell kidolgozói abból indultak ki, hogy az emberi és a szakmai tulajdonságok mind a nyolc területen meghatározzák a tanári tevékenységeket (pedagógia, tananyag, szervezet, technológia, szakmai fejlődés, etika, oktatáspolitika, innováció). A társadalmi változások és a technológiai fejlődés újabb kihívások elé állítják az oktatást a tanári értékek tekintetében is. $\mathrm{Az}$ oktatási problémák egyre változatosabbak, a feladatok pedig egyre összetettebbek. Mind fontosabb, hogy a tanárok müködő megoldásokat találjanak az egyéni helyzetekre, és rugalmasan alkalmazkodjanak a változó környezethez. A dinamikus oktatási környezetben való hatékony munkálkodás etikus magatartást, gyakorlatiasságot, logikus gondolkodást és általában érzékenységet kíván. Ezek a személyes tulajdonságok alapozzák meg a szakmai kompetenciákat, megerősítésük, visszaigazolásuk fontos a tanárképzés során.

A dinamikus leírás tehát nagy hangsúlyt helyez a pedagógus azon személyiségtulajdonságainak és értékeinek fejlődésére, amelyek az IKT-eszközök használatával kapcsolatban a pedagógiai tevékenységük során elengedhetetlenek.

A legfontosabb általános személyes tulajdonságok a becsületesség, megbízhatóság, következetesség, pártatlanság, igazságosság, gondosság, elfogadás, elkötelezettség, együttérzés, igazságkeresés, a személyiség tisztelete.

A legfontosabb szakmai értékek, amelyek kialakítására a tanárképzés során kell sort keríteni:

A tanárnak tudatos szakmai munkát kell folytatnia, amelynek része a folyamatos reflexió, az önképzés, a tevékenységek felülvizsgálata és szükség szerinti módosítása. El kell fogadnia, hogy személyes felelössége a minőségi oktatás, az új szaktárgyi és pedagógiai eredmények, valamint technikai eszközök felhasználása. A szakterületre vonatkozó tudás és az IKT-kompetenciák bővítése nem elegendő, a hiedelmek, attitüdök és értékek kedvező kialakítása szintén a tanárképzés feladatai közé tartozik.

A tanitás szeretete nélkülözhetetlen ahhoz, hogy valaki hosszú ideig képes legyen elhivatottan, a kiégés veszélye nélkül dolgozni a pályán. A tanári hivatás nem egyszerüen szakma, hanem a tanulók javának szolgálata iránti elkötelezettség. Ez a belső jellemző nagyobb szerepet játszik a pályán maradásban, mint a külső elismerés. 
A tanulási folyamat tudatos tervezése azért különösen fontos, mert a tanár minden egyes tanuló fejlődéséért felelős, fel kell ismernie erősségeiket, gyenge pontjaikat és szükségleteiket, majd ezek figyelembevételével kell a tanulási folyamatot megterveznie. Érdekes, biztonságos és támogató környezetet kell teremtenie, amely garantálja a tanulók fizikai, szellemi, érzelmi és intellektuális fejlődését. Értenie kell ahhoz is, hogy kreatívan alkalmazza az informatikai eszközöket a tanításban a tanulás támogatására.

A kollégák iránti tisztelet és bizalom lehet annak a magatartásnak az alapja, amellyel a tanári hivatás tekintélye emelhetö, és amely szavatolja, hogy az alapvető céloknak megfeleljen az adott iskola, mint tanulószervezet. A kollégák közötti együttmüködés a tapasztalatok és a tudás megosztását, az új kollégák támogatását, a befogadásra való nyitottságot is magában foglalja.

A tanári felelösség nem áll meg az osztály falainál, és meghaladja az iskola területét is. Kapcsolatot kell teremteni a szülőkkel, más oktatási intézményekkel, az iparral és az önkormányzattal, társadalmi, vallási és szakmai közösségekkel. Az együttmüködés alapja a nyílt kommunikáció és a gyerekek érdeke.

Végül, de nem utolsó sorban meg kell említeni bizonyos személyiség tulajdonságokat, amelyek a változó társadalomban sikeres helytállásra képes tanár optimális tulajdonságait jelölik: alkalmazkodóképesség, rugalmasság, kreativitás, intuíció, szívósság, együttmüködési képesség, kommunikációs készség, problémamegoldó beállítódás, kockázatvállalási hajlandóság, döntésképesség, motiváló erő, lelkesedés, kreativitás, intellektuális kíváncsiság, pozitív szemlélet, forrásgazdagság, rendszeresség, szervezettség, határozottság, munkabírás - ezek jellemzik az ideális pedagógust. Az oktatási informatika eszköztára sokat segíthet abban, hogy a pedagógusok megközelíthessék ezt az ideált (Midoro, 2005b).

Az informatikai eszközök használatára vonatkozóan szükséges, hogy a pedagógusok eligazodjanak a rendelkezésre álló digitális tananyagok között, képesek legyenek kiválasztani és a helyzethez alakítani a megfelelő forrásokat. Az oktatásmenedzsment-eszközök, például egy-egy virtuális tanulási környezet vagy a digitális napló használata rendszerességet igényel. Kreativitás és képzelőerő szükséges, hogy jó tananyagokat tudjanak készíteni, s megfelelően tudják használni az erre szolgáló eszközöket. Hatékony kommunikációra és a csapatban való munkálkodás képességére van szükség ahhoz, hogy jól használják a digitális kommunikáció eszközeit, és képesek legyenek a kooperatív és kollaboratív munkát alkalmazni a tanítás során.

Az innovatív szemlélet is fontos érték, ez segít abban, hogy új módszerekkel és az IKT alkalmazásával próbálkozzanak. A referenciakeret kidolgozói létrehoztak egy honlapot is, 
(http://www.univirtual.it/uteacher/framework/framework_map.htm), amelyen a modern kor követelményeinek megfelelően interaktív módon tájékozódhatnak az érdeklődők a pedagógusok IKT kompetenciáinak elvárt fejlettségéről a különböző szakmaterületeken.

A Közös Európai Pedagógus IKT-kompetencia Referenciakeret tehát egy olyan elméleti koncepció, amely a személyes, a szakmai tulajdonságok, valamint az értékek szerepét hangsúlyozza ki és a pedagógus IKT-kompetenciák alapjaként határozza meg azokat.

\section{Az 2005-ös ajánlások hatása az azt követő időszakra}

Elméleti áttekintésünk nem lehet teljes annak megemlítése nélkül, hogy mi következett a keretrendszer kidolgozása után. Magyarországon a kilencvenes években végbemenő változások lehetővé tették, hogy a tanárképzésben két folyamat mehessen végbe egymással párhuzamosan. Egyrészt a decentralizáció miatt lehetővé vált, hogy a képző intézmények önmaguk határozzák meg tantervüket, a képzés tartalmát, struktúráját, időtartamát és a minőségi követelményeket. Másrészt figyelembe kellett venniük olyan szabályzókat, amelyek a nemzetközi minőségi sztenderdeknek való megfelelést célozták meg. Ezek a körülmények szerepet játszottak abban, hogy Magyarországon 2009 szeptemberében beindult a mesterszintü tanárképzés, ahol megjelent az IKTképzés az egész ország intézményeire érvényesen az egységes tanári mesterszak alapító dokumentumában, egy félévben, 2 kredit értékben oktatott tantárgyként.

A pedagógus továbbképzésben 2003-ban az OM és az IHM huszonkét modulból álló, ingyenes képzést szervezett tízezer pedagógus részére, és azóta is, minden évben igen sok pedagógus jut ilyen lehetőséghez.

Szintén a pedagógusképzést érintő változás, hogy a pedagógus életpályamodell bevezetéskor (2011), a pedagógusok szakmai kompetenciáinak leírásában megjelent az IKT-kompetencia, de nem külön kompetencia területként, hanem a nyolc kompetenciába ágyazottan (Kotschy, 2011).

Ami pedig a 2005-ben kidolgozott referenciakeretet illeti, először 2008-ban, majd később, 2011-ben bővített formában továbbfejlesztették (UNESCO, 2011, Kárpáti, 2011).

A keretrendszert a következő ábra foglalja össze: 


\begin{tabular}{|c|c|c|c|}
\hline \multicolumn{4}{|c|}{$\begin{array}{c}\text { Az UNESCO által kidolgozott IKT kompetenciák keretrendszere a } \\
\text { pedagógusok számára }\end{array}$} \\
\hline & $\begin{array}{l}\text { Információs } \\
\text { írástudás }\end{array}$ & $\begin{array}{l}\text { Tudás- } \\
\text { elmélyítés }\end{array}$ & $\begin{array}{l}\text { Új tudás } \\
\text { létrehozása }\end{array}$ \\
\hline $\begin{array}{l}\text { az IKT } \\
\text { oktatásbeli } \\
\text { szerepének } \\
\text { tudatosítása }\end{array}$ & $\begin{array}{l}\text { az IKT } \\
\text { oktatásbeli } \\
\text { szerepének } \\
\text { felismerése }\end{array}$ & $\begin{array}{l}\text { az IKT } \\
\text { oktatásbeli } \\
\text { szerepének } \\
\text { megértése }\end{array}$ & $\begin{array}{l}\text { az IKT oktatásbeli } \\
\text { szerepére épülő } \\
\text { innováció }\end{array}$ \\
\hline $\begin{array}{l}\text { tanterv és } \\
\text { értékelés }\end{array}$ & $\begin{array}{l}\text { IKT- } \\
\text { alapismeretek és } \\
\text { készségek } \\
\text { elsajátítása }\end{array}$ & $\begin{array}{l}\text { meglévő } \\
\text { ismeretek, } \\
\text { készségek } \\
\text { alkalmazása }\end{array}$ & $\begin{array}{l}\text { tantervfejlesztés az } \\
\text { IKT-ismeretek és } \\
\text { készségek } \\
\text { birtokában }\end{array}$ \\
\hline $\begin{array}{l}\text { pedagógia/ } \\
\text { módszertan }\end{array}$ & $\begin{array}{l}\text { az IKT } \\
\text { integrálása az } \\
\text { osztályban folyó } \\
\text { nevelő-oktató } \\
\text { munkába }\end{array}$ & $\begin{array}{l}\text { komplex } \\
\text { probléma- } \\
\text { megoldás }\end{array}$ & $\begin{array}{l}\text { a diákok } \\
\text { önszabályozó } \\
\text { tanulásának, } \\
\text { valamint } \\
\text { tudásmegosztásának } \\
\text { támogatása IKT- } \\
\text { eszközök } \\
\text { segítségével }\end{array}$ \\
\hline $\begin{array}{l}\text { IKT } \\
\text { alkalmazás }\end{array}$ & $\begin{array}{l}\text { IKT alap } \\
\text { eszközök } \\
\text { (interaktív tábla, } \\
\text { számítógép) } \\
\text { használata }\end{array}$ & $\begin{array}{l}\text { komplex } \\
\text { eszközhasználat }\end{array}$ & $\begin{array}{l}\text { mindenre kiterjedő } \\
\text { IKT } \\
\text { eszközhasználat }\end{array}$ \\
\hline $\begin{array}{l}\text { szervezési és } \\
\text { adminisztráció } \\
\text { s feladatok }\end{array}$ & $\begin{array}{l}\text { IKT-eszközök } \\
\text { alkalmazása } \\
\text { adminisztrációs } \\
\text { feladatok } \\
\text { ellátására a } \\
\text { sztenderd } \\
\text { osztálymunkához } \\
\text { kapcsolódóan }\end{array}$ & $\begin{array}{l}\text { kollaboratív } \\
\text { csoportmunka }\end{array}$ & $\begin{array}{l}\text { tanulószervezetek- } \\
\text { ben való részvétel }\end{array}$ \\
\hline $\begin{array}{l}\text { tanári } \\
\text { professzionális } \\
\text { önfejlesztés }\end{array}$ & digitális írástudás & $\begin{array}{l}\text { irányítás, } \\
\text { támogatás }\end{array}$ & $\begin{array}{l}\text { a pedagógus, mint } \\
\text { modell a tanuló } \\
\text { számára }\end{array}$ \\
\hline
\end{tabular}

11. ábra: a 2011-es az UNESCO által kidolgozott IKT kompetenciák keretrendszere a pedagógusok számára (Karklins és Tang, 2011. 9.) 
A keretrendszer három pillérre épül:

- az első az információs írástudás (Technology Literacy), amellyel felvértezik a diákokat az IKT eszközök hatékony használatára a tanulási folyamatban,

- a második a tudás elmélyítése (Knowledge Deepening), amellyel felkészítik a diákokat (és munkavállalókat) az egyes tantárgyakban/szakterületeken való mélyebb tudás megszerzésére, és annak alkalmazására komplex, életszerű szituációkban.

- a harmadik, legmagasabb szint az új tudás létrehozása (Knowledge Creation). Ez a szint képessé kell, hogy tegye a diákokat (és munkavállalókat) az új, hasznos tudások létrehozására, amelyek hozzájárulnak a társadalom fejlődéséhez.

Az UNESCO keret modulrendszerüen (összesen 18 modul) a felsorolt 3 szinten, a pedagógus tevékenységek 6 fő irányában került kidolgozásra:

- az IKT oktatásbeli szerepének tudatosítása,

- tanterv és értékelés,

- pedagógia/módszertan,

- IKT alkalmazás,

- szervezési és adminisztrációs feladatok,

- tanári professzionális önfejlesztés.

A modulok részletesen bemutatják az adott területen kitüzött fejlesztési célokat és azokhoz rendelik a szükséges tanulói és pedagógusi kompetenciákat.

Látható tehát, hogy a 2005-ös referenciakeret ajánlásai révén beindultak bizonyos változások egyrészt, a pedagógusképzés és továbbképzés területén, másrészt a keretrendszer, az elméleti modell továbbfejlődött a kompetenciaprofilok átdolgozására került sor. Az átdolgozás során csökkentették a pedagógusok tevékenységi területét, ugyanakkor részletesebb leírásokat adtak az egyes területeken kitüzött fejlesztési célok, a tanulók és a pedagógusok kompetenciái vonatkozásában. 


\section{7. Összegzés}

Az IKT-eszközök hatékony alkalmazása új elvárásokat támaszt a pedagógusokkal szemben. Nem elég, ha a pedagógus képes a számítógép használatára, ennél többre van szükség, a korszerü pedagógiai elvek és módszertani eszközök ismeretére és alkalmazására. A megújulás egyik iránya a pedagógusok IKTkompetenciákkal való felvértezése annak érdekében, hogy eredményesen használhassák azokat a nevelö-oktató munkájukban. 2005 júniusában tették közzé a tanárok oktatási informatikai (IKT) kompetenciájának közös európai referenciakeretét, amely az U-Teacher Projekt eredményeként készült el. Maga a referenciakeret nem elózmények nélküli. Már korábban megtörtént bizonyos személyiségtulajdonságok és kompetenciák meghatározására az IKT-eszközöket adaptívan alkalmazó tanár ideális modelljének megalkotásához. A referenciakeret ezt tovább gondolta és egy elméleti modellbe helyezte. A referenciakeret a reflektív pedagógust állítja a középpontba, aki a szakmai munkája során annak különböző területeit művelve és a tevékenysége során különböző személyekkel és szervezetekkel kapcsolatba kerülve adaptív módon képes alkalmazkodni a technológiai fejlődés és a környezeti átalakulás diktálta változásokhoz. A reflektivitás igénye által hajtva a modellt továbbfejlesztették bizonyos dimenzióit kiemelve, bizonyos dimenzióit pedig egyszerüsítve. 


\section{Felhasznált irodalom}

Kárpáti Andrea (2007): Tanárok informatikai kompetenciájának fejlesztése. Bevezetés egy tematikus összeállításhoz. Iskolakultúra, 17. 4., 3-7.

Kárpáti Andrea és Hunya Márta (2009a): Kísérlet a tanárok IKT-kompetenciája közös európai referenciakeretének kialakítására-A U-Teacher projekt I., Új Pedagógiai Szemle, 2009. 59.2. 95-106., http://ofi.hu/karpati-andreahunya-marta-kiserlet-tanarok-ikt-kompetenciaja-kozos-europaireferenciakeretenek-0, letöltve 2017 december 10.

Kárpáti Andrea és Hunya Márta (2009b): Kísérlet a tanárok IKT-kompetenciája közös európai referenciakeretének kialakítására - a U-Teacher Projekt II. Új Pedagógiai Szemle, 2009. 59.3. 83-119. http://ofi.hu/karpati-andreahunya-marta-kiserlet-tanarok-ikt-kompetenciaja-kozos-europaireferenciakeretenek.letöltve 2017. december 2.

Kárpáti Andrea (2011): Digital Literacy in Education. UNESCO Policy Brief. UNESCO Institute for Information Technologies in Education, Moscow. Online: http://unesdoc.unesco.org/images/0021/002144/214485e.pdf

Kotschy Beáta (szerk.) (2011): A pedagógussá válás és a szakmai fejlődés sztenderdjei, Eszterházy Károly Főiskola, Eger,

Midoro, V. (szerk.) (2005a): European Teachers Towards a Knowledge Society. Ortona, Edizioni Menabo Didactica.

Midoro, V. (szerk.) (2005b): A Common European Framework for Teachers' Professional Profile in ICT for Education, Menabò, Ortona

Midoro, V. és mtsai (2005): U-Teacher a European project on teachers' professional profile in ICT for education, http://www.egger.ac/1docs/booklet2b.pdf, letöltve 2017. december 2.

Racskó Réka (2016): Összehasonlító vizsgálatok a digitális átállás módszertani megalapozásáról, Doktori disszertáció, Eger. https://www.researchgate.net/publication/316594905, letöltve 2017. december 4. https://doi.org/10.17717/IQKONYV.Racsko.2017

Anderson, J., van Weert, T. és Duchâteau, C. (szerk.) (2002): Information and communication technology in education: a curriculum for schools and programme of teacher development. UNESCO. Párizs 
Karklins, J. és Tang, Q. (szerk.) (2011): UNESCO ICT Competency Framework for Teachers. UNESCO, Párizs.

http://unesdoc.unesco.org/images/0021/002134/213475e.pdf, letöltve: 2017. december 16. 